\title{
ONLINE MARKETING ACCESSIBILITY AND BEHAVIOR AMONG BATIK ENTREPRENEURS IN LAWEYAN, SURAKARTA, CENTRAL JAVA
}

\author{
Meutia Sistarani, Indriana, Rosalin Ayal, Adhi Bawono \\ Universitas Bina Nusantara, Jakarta \\ meutia.sistarani@binus.ac.id
}

\begin{abstract}
In this study, researchers are evaluating the accessibility of online marketing, the most preferable online shops among consumers and the income earned each month generated through it. This research is using a qualitative method on respondents from the batik entrepreneurs' in Laweyan, Surakarta, Central Java. The primary and secondary data are collected at every research stage. Those data are further analyzed using interactive model data analysis. As a result, it was concluded that batik entrepreneurs in Laweyan are actively engaged with social media, but only a few of them are capable to utilize it for their marketing activities. The main reason is due to the limited human resource capable to run an online shop effectively, therefore most of them prefer to sell their goods in a traditional offline store basis. It is very unfortunate, because we also discovered that among batik entrepreneurs who already applied online marketing, their income has increased significantly. From this research, we suggest batik entrepreneurs in Laweyan, Surakarta, Central Java to actively use online shop as an option to market and distribute their product. They could spare some time, at least once a week, to update their business social media, ecommerce page, or business website. By doing this, batik entrepreneurs could increase their income and wider their business.
\end{abstract}

Keywords: Online Marketing; Online Shop; Batik Entrepreneurs

\section{INTRODUCTION}

The use of online shops is increasing along with the increasingly sophisticated technology that makes entrepreneurs race to dominate the market. Online shop offers convenience in transactions, marketing and communication media. In addition, the existence of an online shop will further save operational costs related to rental premises.
Laweyan, which located in Surakarta, Central Java, is a famous center for batik production. This batik industry has long existed in the Surakarta area, because culturally, people in this city often use batik as clothing.

At Laweyan, batik was not only produced in the form of clothing, but also in the form of shoes, shirts, sleep equipment and so on. In Laweyan, offline transactions are still carried out because usually consumers came to offline stores 
EAJ (Economics and Accounting Journal) - Vol. 3, No. 2, May 2020 -Sistarani, Indriana, Ayal \& Bawono

to know more about the quality of the batik. But it is also possible that these batik entrepreneurs market their goods through online shops such as the web, blog or social media.

Compared to the traditional way of conducting business, doing business by online could help entrepreneurs in solving problems easily and quickly. Consumers can find various products and services, and make a comparison between them, especially with the help of social media (Durmaz \& Efendioglu, 2016). Entrepreneurs could contact their consumers, update the newest product of their business, and increase their business awareness easily by having an online shop.

In traditional marketing, consumers can see and touch the products but the domain of effect is low, on the other hand, using online marketing will exceed the boundaries and introduce goods and services to the demographic of internet users (Salehi, 2012). Indonesia is ranked as the fourth highest internet penetration in the world, and estimated to growth $8,56 \%$ in 2020 (Stats, 2019). This number can be further seen as containing potential customers to entrepreneurs if they conduct online business. Online marketing strategy includes all business efforts which is done to market products or services through or using online media, namely internet.

Based on the explanation above, the authors raise "how is the online marketing accessibility and behavior in the marketing process for batik entrepreneurs in Laweyan, Surakarta, Central Java?" as the problem identification for this research.

\section{LITERATURE REVIEW}

According to (Astuti, 2016) online business can be used as an alternative to running a business with relatively smaller capital or even no capital at all. Anyone can run it both in their teens, adulthood and old age. It is this convenience that then drives the birth of what is commonly referred to as online shops.

Added by (Prabowo et al., 2017) the use of various web, blogs and social media personally makes it easier for users to conduct transactions. The use of social media is then developed from its original purpose as a friendship site and the exchange of information into an area of marketing facilities for a product. The use of social media in addition to finding information is also to run an online business. Usually, these online business accounts offer their products with interesting photos or videos (Fildzah \& Sari, 2017).

Added by (Commerce, 2016) marketing is the key to achieving customer interest, winning customer purchase, earning customer satisfaction and loyalty, and keeping your small business in business. (Kotler \& Keller, 2012) also added that marketing is about identifying and meeting human and social needs.

Explained by (Salo, 2017) since the emergence of social media, industrial marketing academics and marketers have also been intrigued by the influence of such media on the discipline. As, social media research in the field of industrial marketing has been of increasing interest, this research attempts to review and assess the advances in social media research in the industrial marketing field. Added by (Pinto \& Yagnik, 2016) In the evolving landscape of integrated marketing communications, social media marketing is growing exponentially.

According to (Razali, Saraih, Shaari, Abd Rani, \& Abashah, 2018), the key of online business effectiveness is its ability to target the right customers, cost efficiency, and analytics. Several studies finding shows that the use of e-business increase sales and can reduce business costs and improve productivity of the business (Ashrafi \& Murtaza, 2008). 
EAJ (Economics and Accounting Journal) - Vol. 3, No. 2, May 2020 -Sistarani, Indriana, Ayal \& Bawono

Added by (Rafa'al, 2017), principally, consumer behavior is influenced by consumer affection and cognition of a product, where the two factors can also be influenced by the environment and the stimulus that was provided by the marketer of the product itself. (Febriani, 2017) added that if consumers are constantly having trouble finding the product they want, then over time, consumers will try to other brands.

\section{RESEARCH METHOD}

This research uses a qualitative approach. Bungin (2013) revealed that qualitative approach is a research work process with limited targets, but the depth of the data is not limited. The deeper and more quality of the data obtained or collected, the results of the study will be better. Qualitative research is therefore concerned with aspects of reality that cannot be quantified, focusing on the understanding and explanation of the dynamics of social relations (Queiros, Faria, \& Almeida, 2017).

The nature of the research used by researchers is descriptive. A qualitative descriptive approach as described by (Sandelowski, 2010) informed the design, collection, and analysis of data.

The sources of data in a research are people and objects, which can provide information, facts, data and reality that are related or relevant to what is studied or researched, Ibrahim (2015). In obtaining primary data, researchers conduct in-depth interviews and observations to batik entrepreneurs who were the members of the Laweyan Batik Kampoeng Forum. The secondary data collection techniques conducted by researchers are the study of literature and online data.

Here is a flowchart of this research:

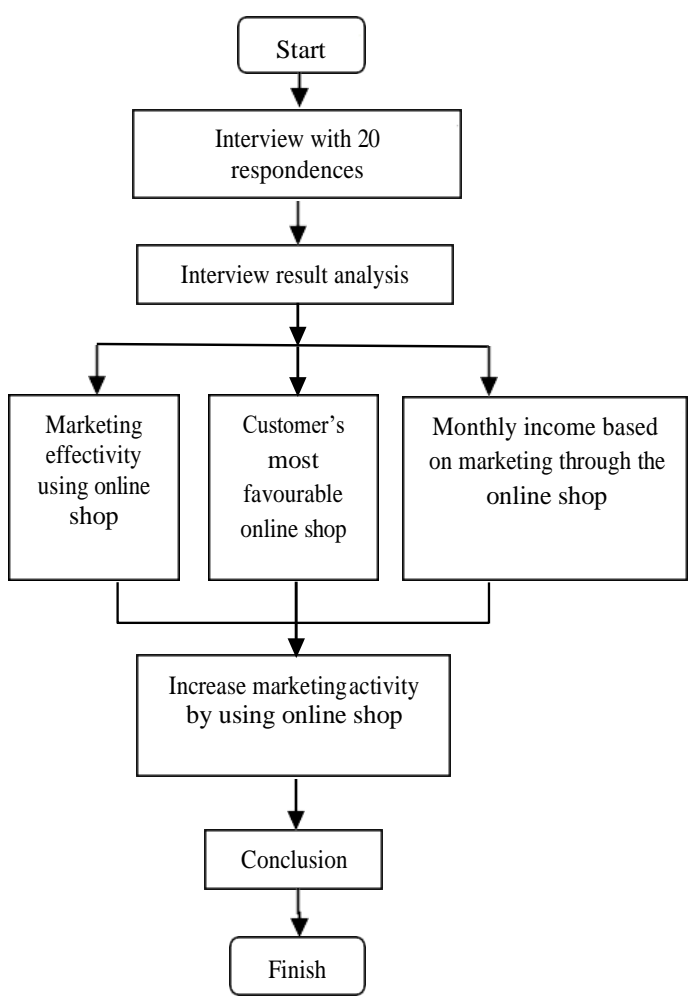

Figure 1: Research Flowchart

\section{Source: Primary Data}

Researchers had the opportunity to visit Kampoeng Batik Laweyan to conduct this research. There are about 70 batik entrepreneurs who reside in this location. Some of them are members of the Forum Kampoeng Batik Laweyan (FKBL) community. In this study, researchers collected data on 20 batik entrepreneurs who were the members of the Laweyan Batik Kampoeng Forum. The selection of 20 batik entrepreneurs was also the result of discussions with the chairman of FKBL, who suggested batik entrepreneurs from several customer segmentation targets, business sizes, and types of batik produced.

Table 1. List of Batik Entrepreneur's Respondent

No Business Name

1 Batik Mahkota Laweyan 
EAJ (Economics and Accounting Journal) - Vol. 3, No. 2, May 2020 -Sistarani, Indriana, Ayal \& Bawono

\begin{tabular}{cc}
\hline 2 & Batik Gunawan Desain \\
3 & Batik Pandono \\
4 & Batik Cempaka \\
5 & Batik Jofa \\
6 & Batik Puspa Kencana \\
7 & Batik Setya \\
8 & Batik Marin \\
9 & Batik Gres Tenan \\
10 & Batik Merak Manis \\
11 & Batik Putra Laweyan \\
12 & Batik Estu Mulyo \\
13 & Batik Puspita Mekar \\
14 & Batik Naluri \\
15 & Batik Damar Kusumo \\
16 & Batik Putra Bengawan \\
17 & Batik Omah Laweyan \\
18 & Batik Ivy \\
19 & Batik Citra Kencana \\
20 & Batik s128 \\
21 & Batik Soga \\
22 &
\end{tabular}

Source: Primary Data

\section{RESULTS AND DISCUSSION}

\subsection{Marketing Through Online Shop}

The majorities of entrepreneurs in Laweyan, Surakarta, Central Java produce written batik and printed batik with their own characteristics. Others createbatik in written form with architectural, heritage, abstract and contemporary styles.

The rapid development of information and technology, directly or indirectly, will have an impact on people's daily activities. This increasingly advanced technology must be utilized as well as possible by entrepreneurs as an opportunity to advance the business they are doing.

The presence of technology makes it easier for humans to carry out daily activities, including buying and selling. Nowadays, consumers and producers are increasingly practical and favor instant things rather than the traditional way. Therefore, buying and selling products through social media can be the right choice. Without having to do face-to-face meetings, the internet can be an easy and clear medium of sales information, both in the presence of writing and with visuals. In addition, unlimited reach will make it easier for an entrepreneur to expand his business into the international market. So it is an important thing for an entrepreneur, both small businesses and large businesses, to market their products through the internet to maximize sales.

The results of interviews conducted by researchers revealed that batik entrepreneurs in Laweyan tried to introduce the products they produce through a number of ways, such as; through word of mouth that had been carried down from generation to generation since 1942; through opening stores and becoming suppliers to several department stores in Jakarta; through social media; via online messenger (WhatsApp); through exhibitions held by local government, cultural organizations, and when there are certain events; through training provided to tourists and school students; through collaboration with batik or fashion brands that already have big names; and through visits held by certain schools, industries and organizations.

One of the activities carried out by several batik entrepreneurs in introducing their products is through training. Another activity undertaken by batik entrepreneurs in Laweyan to introduce their products is to open up to visits from school students, certain industries, and certain organizations. 
EAJ (Economics and Accounting Journal) - Vol. 3, No. 2, May 2020 -Sistarani, Indriana, Ayal \& Bawono

From the interviews, researchers also learned that batik entrepreneurs in Laweyan had begun to use technological assistance in marketing their products.

The majority of them have marketed through online shops and online messengers, which are free of charge. However, marketing done through the online shop has not been effective because some things such as not too focused on online sales, not really understanding the process and how to optimize the online shop, limited time to upload images and reply to messages, do not have a big picture of marketing strategies, do not "catch" consumers who have visited an online shop, and rarely updating news or pictures on online sites.

After speaking further with the respondences, it was discovered that the ineffectiveness of marketing through an online shop for batik entrepreneurs in the Laweyan region was caused partly because there were no employees ready to accept consumers via online; just following the trend, that many stores sell online; online media are only used as news and branding; and the lack of online shop training that the batik entrepreneurs get.

\subsection{Interest to Online Shop}

When talking about whether Laweyan batik entrepreneurs were interested or not towards online shops, all of them said that they were interested in marketing products online. They argue that by marketing products online, they can reach wider consumers. Consumers who cannot come directly to the store, or visit the city of Solo, can see the products they offer in the online store. The products they offer can be sold to consumers outside the city, outside the island, even overseas. Consumers only need to order and pay, and then the batik businessman only needs to send the product through certain goods shipping services. The coverage area that can be reached is very broad, especially with internet users in
Indonesia which have reached more than 130 million people.

The number of online shops that offer pages on the website or application for free is also the main attraction. Withzero cost, the batik entrepreneurs are interested to open an online shop. Social media like Facebook, Instagram and Twitter are still offered for free. Anyone can create an account to sell online easily. Blogs and websites with their own names are also offered for free. Even batik entrepreneurs can market goods on various e-commerce websites free of charge.

Among the various activities of running a batik business, selling products online can be an activity carried out in spare time. Because of the flexible sales times, batik entrepreneurs can take care of sales and deliver orders at night, after all the work in the offline store is carried out. Batik entrepreneurs are free to set their online activity according to their capacity and time.

From the interviews, researchers obtained data that as of 2014, batik entrepreneurs in the Laweyan area had started marketing products online. Batik Cempaka and Batik Puspita Mekar, for example, started to have Instagram accounts @batik_cempaka as of April 2014 and @batikpuspitamekar as of August 2014, which are still active until today.

Table 2. List of Online Shop Used by Laweyan Batik Businesses

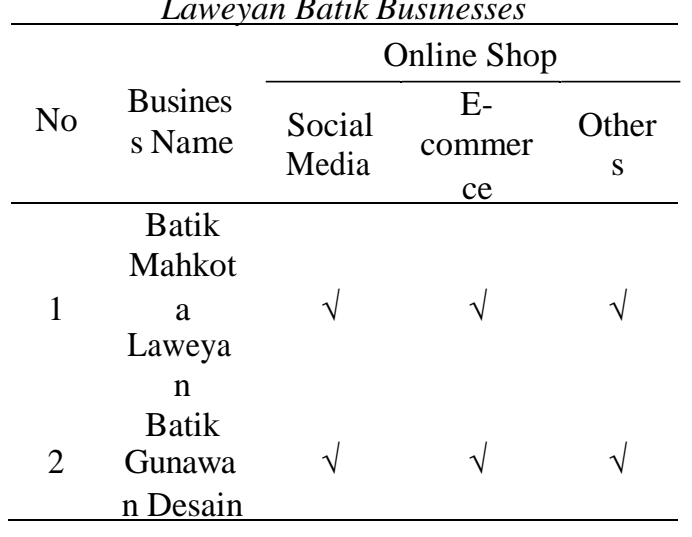


EAJ (Economics and Accounting Journal) - Vol. 3, No. 2, May 2020 -Sistarani, Indriana, Ayal \& Bawono

\begin{tabular}{|c|c|c|c|c|}
\hline 3 & $\begin{array}{c}\text { Batik } \\
\text { Pandono } \\
\text { Batik }\end{array}$ & $\sqrt{ }$ & - & $\sqrt{ }$ \\
\hline 4 & $\begin{array}{c}\text { Cempak } \\
\mathrm{a}\end{array}$ & $\sqrt{ }$ & $\sqrt{ }$ & $\sqrt{ }$ \\
\hline 5 & $\begin{array}{c}\text { Batik } \\
\text { Jofa } \\
\text { Batik }\end{array}$ & $\sqrt{ }$ & $\sqrt{ }$ & $\sqrt{ }$ \\
\hline 6 & $\begin{array}{l}\text { Puspa } \\
\text { Kencana } \\
\text { Batik }\end{array}$ & $\sqrt{ }$ & - & $\sqrt{ }$ \\
\hline 8 & $\begin{array}{l}\text { Setya } \\
\text { Batik } \\
\text { Marin }\end{array}$ & $\sqrt{ }$ & - & $\sqrt{ }$ \\
\hline 9 & $\begin{array}{c}\text { Batik } \\
\text { Gres } \\
\text { Tenan } \\
\text { Batik }\end{array}$ & $\sqrt{ }$ & $\sqrt{ }$ & $\sqrt{ }$ \\
\hline 10 & $\begin{array}{l}\text { Merak } \\
\text { Manis } \\
\text { Batik }\end{array}$ & $\sqrt{ }$ & - & $\sqrt{ }$ \\
\hline 11 & $\begin{array}{c}\text { Putra } \\
\text { Laweya } \\
n\end{array}$ & & & \\
\hline 12 & $\begin{array}{c}\text { Batik } \\
\text { Estu } \\
\text { Mulyo }\end{array}$ & $\sqrt{ }$ & - & $\sqrt{ }$ \\
\hline 13 & $\begin{array}{l}\text { Batik } \\
\text { Puspita } \\
\text { Mekar }\end{array}$ & $\sqrt{ }$ & $\sqrt{ }$ & $\sqrt{ }$ \\
\hline 14 & $\begin{array}{l}\text { Batik } \\
\text { Naluri } \\
\text { Batik }\end{array}$ & $\sqrt{ }$ & - & $\sqrt{ }$ \\
\hline 15 & $\begin{array}{c}\text { Damar } \\
\text { Kusumo }\end{array}$ & $\sqrt{ }$ & - & $\sqrt{ }$ \\
\hline 16 & $\begin{array}{c}\text { Batik } \\
\text { Putra } \\
\text { Bengaw } \\
\text { an } \\
\text { Batik }\end{array}$ & $\sqrt{ }$ & $\sqrt{ }$ & $\sqrt{ }$ \\
\hline \multirow[t]{2}{*}{17} & $\begin{array}{c}\text { Omah } \\
\text { Laweya } \\
n\end{array}$ & $\sqrt{ }$ & $\sqrt{ }$ & $\sqrt{ }$ \\
\hline & & $\sqrt{ }$ & $\sqrt{ }$ & - \\
\hline 18 & $\begin{array}{c}\text { Batik } \\
\text { Ivy } \\
\text { Batik }\end{array}$ & $\sqrt{ }$ & - & $\sqrt{ }$ \\
\hline 19 & $\begin{array}{c}\text { Citra } \\
\text { Kencana } \\
\text { Batik }\end{array}$ & $\sqrt{ }$ & - & $\sqrt{ }$ \\
\hline 21 & $\begin{array}{l}\text { Batik } \\
\text { Soga }\end{array}$ & $\sqrt{ }$ & - & - \\
\hline 22 & $\begin{array}{c}\text { Batik } \\
\text { Pria } \\
\text { Tampan }\end{array}$ & $\sqrt{ }$ & $\sqrt{ }$ & $\sqrt{ }$ \\
\hline
\end{tabular}

\begin{tabular}{llll}
\hline \multicolumn{3}{c}{ Batik } \\
Putu \\
Laweya \\
$\mathrm{n}$
\end{tabular}

From the data collection it is also known that the majority of batik entrepreneurs in Laweyan were already familiar with Instagram and Facebook, and have a website with their own batik shop name. However, despite having an online shop, the use and marketing through online has not been done optimally. The majority of social media accounts and websites owned by batik entrepreneurs are not up to date and not active.

The majority of batik entrepreneurs in Laweyan have not used sales media through e-commerce sites in Indonesia. This is caused by their lack of knowledge about e-commerce sites and the absence of organizations that provide them with training in e-commerce.

The results of researcher's interviews with several batik entrepreneurs in Laweyan also obtained data that almost all batik businesses in Laweyan have Instagram and Facebook accounts. Almost all of them also have a website with their own shop name, and almost all of them also have a WhatsApp number for the process of buying and selling products.

Of all the online shops used to market the products, Instagram and WhatsApp are most in demand by consumers when they buy batik products made by batik entrepreneurs in the Laweyan region, Surakarta, Central Java. This can be caused because the majority of batik entrepreneurs can be contacted via WhatsApp, which makes WhatsApp as one of the main communication media in their activities. So consumers who want to buy their product can be connected quickly via WhatsApp. Meanwhile, buying through Instagram is also in great demand by consumers. This is caused by photos of products displayed on 
EAJ (Economics and Accounting Journal) - Vol. 3, No. 2, May 2020 -Sistarani, Indriana, Ayal \& Bawono

Instagram along with explanations that make consumers more confident in the purchase process.

\subsection{Income Through Online Shop}

Because the majority of batik businesses in the Laweyan area are now a hereditary effort from parents, the calculation of income, expenses, profits, and losses is still done manually and traditionally. Some entrepreneurs also combine business finances with their household finances.

Interviews conducted by researchers on site produced data that $50 \%$ of batik entrepreneurs already knew and carried out modern trading calculations, using applications on mobile phones or with the help of Microsoft Excel on computers. While the other $50 \%$ are still using the traditional method, written in a book.

When compared to before using online media, income with the help of an online shop is quite high. One respondent can earn up to 700 million IDR per year after using an online shop as one of their marketing media. Other respondents can sell 750 pieces of batik every month through offline media (stores), and by using the online shop these respondents can increase sales up to twice as much per month.

\section{REFERENCES}

Ashrafi, R., \& Murtaza, M. (2008). Use and Impact of ICT on SMEs in Oman. Electronic Journal Information Systems Evaluation, 11(3), 125-138.

Astuti, A. B. (2016). Analisis Strategi Pemasaran Media Sosial Pada Online Shop. Kreator, 03, 1-10.

Bungin, B. (2013). Metode Penelitian Sosial dan Ekonomi. Jakarta: Kencana Prenada Media.

Commerce, U. S. C. of. (2016). Small

\section{CONCLUSION}

Based on the research that has been done in the use of online shop in the marketing process of batik entrepreneurs in Laweyan, Surakarta, Central Java, it can be concluded that batik entrepreneurs in Laweyan are familiar with social media, but only a few of them use social media / online shop in marketing their products. The use of online shops has not been effectively used by batik entrepreneurs in Laweyan. The majority are due to the unavailability of resources to run an online shop and the desire to focus more on the offline shop. Some batik entrepreneurs who have an online shop that regularly updated can market their products effectively compared to before. The majority of batik entrepreneurs in Laweyan use social media such as Instagram, Facebook, Tokopedia, Bukalapak, Shopee, shop websites, and WhatsApp in offering their products online. The majority of consumers buy products online through Instagram and WhatsApp. Especially for batik entrepreneurs who are active online, they claim that their income level is increasing compared to if they do not use online marketing.

Business Marketing Strategies. New Jersey: John Wiley and Sons. Durmaz, Y., \& Efendioglu, I. H. (2016). Travel from Taditional Marketing to Digital Marketing. Global Journal of Management and Business Research: E-Marketing, 16(2).

Febriani, N. S. (2017). Faktor Kebudayaan Pendorong Munculnya Loyalitas pada Konsumen Kuliner Kota Kediri Jawa Timur. Jurnal Studi Komunikasi, $\quad$ I(3). 
EAJ (Economics and Accounting Journal) - Vol. 3, No. 2, May 2020 -Sistarani, Indriana, Ayal \& Bawono

https://doi.org/10.25139/jsk.v1i3.2 96

Fildzah, N. A., \& Sari, D. (2017). Pengaruh Celebrity Endoser Dan Word Of Mouth Terhadap Keputusan Pembelian Produk Sweater Online Shop Alco Di Media Sosial Instagram. Bisnis, Administrasi Komunikasi, Fakultas Telkom, Universitas, 11(2), 99112.

Ibrahim. (2015). Metodologi Penelitian Kualtitatif. Bandung: Alfabeta.

Kotler, P., \& Keller, K. L. (2012). Marketing Mix. New Jersey: Pearson Prentice Hall, Inc.

Pinto, M. B., \& Yagnik, A. (2016). Fit for life: A content analysis of fitness tracker brands use of Facebook in social media marketing. Journal of Brand Management, 2015. https://doi.org/10.1057/s41262016-0014-4

Prabowo, Y. D., Rusli, M., Teknologi, I., Jl, K., Selatan, P., \& Timur, J. (2017). Faktor yang mepengaruhi Keputusan Pembelian Ulang pada Forum Jual Beli, 3, 63-73.

Queiros, A., Faria, D., \& Almeida, F. (2017). Strengths and Limitations of Qualitative and Quantitative Research Methods. European Journal of Education Studies, 3(9), 369-387.

Rafa'al, M. (2017). Identitas Gaya Hidup dan Buaya Konsumen dalam
Mengkonsumsi Brand The Executive. Jurnal Komunikasi Profesional, 1(1).

Razali, R., Saraih, U. N., Shaari, M. S., Abd Rani, M. J., \& Abashah, A.

(2018). The Influences of Effectiveness, Competitive Advantages and Market Accessibility on SME Performance in Malaysia. In MATEC Web of Conferences.

https://doi.org/https://doi.org/10.10 51/matecconf/201815005023

Salehi, M. (2012). Dissimilarity of EMarketing vs Traditional Marketing. International Journal of Academic Research in Business and Social Sciences, 2(1), 510-515.

Salo, J. (2017). Social media research in the industrial marketing field: Review of literature and future research directions. Industrial Marketing Management, (November 2016), 0-1. https://doi.org/10.1016/j.indmarma n.2017.07.013

Sandelowski, M. (2010). What's in A Name? Qualitative Description Revisited. Research in Nursing and Health, 33(1), 77-84.

Stats, I. W. (2019). Top 20 Countries With The Highest Number of Internet Users. Retrieved May 13, 2020, from https://www.internetworldstats.co $\mathrm{m} / \mathrm{top} 20 . \mathrm{htm}$ 